\title{
Article \\ Development of a Novel Low-Silver Cu-P Brazing Filler Metal Bearing Sn
}

\author{
Jie Wu, Songbai Xue * ${ }^{(D)}$ and Qingcheng Luo
}

check for

updates

Citation: Wu, J.; Xue, S.; Luo, Q. Development of a Novel Low-Silver $\mathrm{Cu}-\mathrm{P}$ Brazing Filler Metal Bearing Sn. Crystals 2022, 12, 66. https:/ / doi.org/10.3390/cryst12010066

Academic Editor: Fan Jiang and Mingxuan Yang

Received: 24 November 2021 Accepted: 27 December 2021 Published: 4 January 2022

Publisher's Note: MDPI stays neutral with regard to jurisdictional claims in published maps and institutional affiliations.

Copyright: (C) 2022 by the authors. Licensee MDPI, Basel, Switzerland. This article is an open access article distributed under the terms and conditions of the Creative Commons Attribution (CC BY) license (https:// creativecommons.org/licenses/by/ $4.0 /)$.

\author{
College of Materials Science and Technology, Nanjing University of Aeronautics and Astronautics, \\ Nanjing 210016, China; zsb@nuaa.edu.cn (J.W.); lqc03@nuaa.edu.cn (Q.L.) \\ * Correspondence: xuesb@nuaa.edu.cn; Tel.: +86-025-8489-6070
}

\begin{abstract}
The flame brazing of $\mathrm{H} 62$ brass using a novel, low-silver Cu-P brazing filler metal was investigated in this study. The effect of the addition of a trace amount of Sn on the microstructure and properties of $\mathrm{Cu}-7 \mathrm{P}-1 \mathrm{Ag}$ filler metals was analyzed by means of X-ray diffractometer, scanning electron microscopy and energy dispersive spectrometer. The addition of trace Sn led to a decrease in the solidus and liquidus temperatures of $\mathrm{Cu}-7 \mathrm{P}-1 \mathrm{Ag}$ filler metals. Meanwhile, the spreading performance of the filler metals on a $\mathrm{H} 62$ brass substrate was improved. The microstructure of the low-silver, $\mathrm{Cu}$-P brazing filler metal was mainly composed of $\alpha$-Ag solid solution, $\alpha$-Cu solid solution and $\mathrm{Cu}_{3} \mathrm{P}$; an increase of $\mathrm{Sn}$ content led to the transformation of the microstructure of the joints from a block to a lamellar structure. When the Sn content was $0.5 \mathrm{wt}$. \%, the shear strength of the joint at room temperature reached $348 \mathrm{MPa}$, and the fracture morphologies changed from a cleavage to a quasi-cleavage structure.
\end{abstract}

Keywords: low-silver Cu-P filler metals; melting temperature; spreading performance; microstructure; mechanical properties

\section{Introduction}

Cu-P brazing filler metals are extensively used to braze copper and its alloys in the aerospace, electronics, energy, transportation, military, automobile, and other industries due to their superior performance, such as low melting point, good wettability, low price and self-brazing property when brazing pure $\mathrm{Cu}[1,2]$. Elemental $\mathrm{P}$ can greatly reduce the melting temperature of the filler metal and increase the spreading area on the substrate [3]. However, the content of $\mathrm{P}$ in the $\mathrm{Cu}-\mathrm{P}$ brazing filler metals is relatively high, and the alloy matrix contains a large amount of brittle $\mathrm{Cu}_{3} \mathrm{P}$ compounds, resulting in poor plasticity at room temperature [4]. In addition, the melting temperature of $\mathrm{Cu}-\mathrm{P}$ brazing filler metal is still too high to braze copper alloys with low melting points, such as brass. Therefore, several novel $\mathrm{Cu}-\mathrm{P}$ brazing filler metals have been developed, such as $\mathrm{Cu}-\mathrm{P}-\mathrm{Ni}[5,6], \mathrm{Cu}-\mathrm{P}-$ $\mathrm{Ag}$ [7], Cu-P-Sn [8,9], Cu-P-Zr [10] and Cu-P-RE (rare earth) [11], some of which have been used in the manufacturing industry for brazing copper alloys.

Compared with $\mathrm{Cu}-\mathrm{P}$ brazing filler metals, $\mathrm{Cu}-\mathrm{P}-\mathrm{Ag}$ series alloys show lower melting points and better wettability. Meanwhile, brittle $\mathrm{Cu}_{3} \mathrm{P}$ compounds in the brazing filler metal matrix can form eutectic structures with $\alpha$-Ag solid and $\alpha$-Cu solid solutions, which greatly improves the plasticity and processing properties of the brazing filler metals. As such, this approach has been widely used in the electronics industry [12]. However, the price of silver is extremely high and volatile, which limits the application of high-silver $\mathrm{Cu}-\mathrm{P}-\mathrm{Ag}$ filler metals in middle- and low-end manufacturing. The melting point of $\mathrm{Sn}$, which is a relatively cheap metal, is only $231.9^{\circ} \mathrm{C}$. Adding Sn to Cu-P brazing filler metals can greatly decrease their solidus and liquidus temperatures and improve their flowability [13]. Furthermore, appropriate amounts of Sn can dissolve in copper to form copper-based solid solutions. The strengthening effect of these solutions can improve the mechanical 
properties of $\mathrm{Cu}-\mathrm{P}$ brazing filler metals. However, Sn has limited solid solubility in copper, and excessive $\mathrm{Sn}$ can form brittle intermetallic compounds with $\mathrm{Cu}$, negatively affecting the mechanical properties of the filler metals [14].

In order to reduce the cost of high-silver $\mathrm{Cu}-\mathrm{P}$ brazing filler metals, in this study, $\mathrm{Cu}-7 \mathrm{P}-1 \mathrm{Ag}$ filler metals with various $\mathrm{Sn}$ additions were produced. The effect of Sn addition on the melting characteristics and spreading performance of novel $\mathrm{Cu}-7 \mathrm{P}-1 \mathrm{Ag}$ brazing alloys was investigated, and the microstructures and phase were analyzed. Additionally, the mechanical properties and fracture morphologies of brazed joints were studied.

\section{Materials and Methods}

Pure $\mathrm{Cu}, \mathrm{Ag}$ and $\mathrm{Sn}$, as well as $\mathrm{Cu}-14 \mathrm{P}$ master alloy, were used as raw materials. These metals were melted in a medium frequency furnace (frequency $600 \mathrm{~Hz}$, power $110 \mathrm{~kW}$ ). The molten alloy was subsequently held for $20 \mathrm{~min}$ and then poured into a $50 \mathrm{~mm}$ diameter steel mould. Finally, all the cast ingots were extruded (Hydraulic Press, Xinke Y32-315) into wire with a $1.9 \mathrm{~mm}$ diameter for brazing. The designed and actual compositions of the Cu-7P-1Ag- $x$ Sn filler metals used in present study are listed in Table 1.

Table 1. Designed and actual compositions of the Cu-7P-1Ag- $x$ Sn filler metals (wt. \%).

\begin{tabular}{|c|c|c|c|c|c|c|c|}
\hline \multirow{2}{*}{ No. } & \multirow{2}{*}{$\mathrm{Cu}$} & \multicolumn{2}{|c|}{$\mathbf{P}$} & \multicolumn{2}{|c|}{ Ag } & \multicolumn{2}{|c|}{ Sn } \\
\hline & & Designed & Actual & Designed & Actual & Designed & Actual \\
\hline 1 & Bal. & 7.00 & 6.96 & 1.00 & 1.02 & 0 & 0 \\
\hline 2 & Bal. & 7.00 & 6.99 & 1.00 & 0.98 & 0.10 & 0.11 \\
\hline 3 & Bal. & 7.00 & 7.03 & 1.00 & 1.00 & 0.30 & 0.31 \\
\hline 4 & Bal. & 7.00 & 6.95 & 1.00 & 0.98 & 0.50 & 0.52 \\
\hline 5 & Bal. & 7.00 & 6.93 & 1.00 & 1.05 & 0.70 & 0.70 \\
\hline 6 & Bal. & 7.00 & 7.06 & 1.00 & 1.03 & 1.00 & 1.04 \\
\hline
\end{tabular}

The commercially supplied H62 brass substrates used in the present work were processed into plates with the dimensions of $40 \mathrm{~mm} \times 40 \mathrm{~mm} \times 1 \mathrm{~mm}$ for the spreading test and $60 \mathrm{~mm} \times 25 \mathrm{~mm} \times 3 \mathrm{~mm}$ for the shear test. All filler metals and specimen surfaces were polished by $\mathrm{SiC}$ papers in order to remove the oxide layer, and then ultrasonically cleaned by ethanol.

The solidus and liquidus temperatures of the brazing alloys were determined using a differential scanning calorimeter (DSC, Netzsch STA 449F, NETZSCH Group, Selb, Germany) under a nitrogen atmosphere with heating at a rate of $10^{\circ} \mathrm{C} / \mathrm{min}$. The spreading test was carried out according to China's National Standard GB/T 11364-2008 [15]. First, $200 \mathrm{mg}$ of each novel filler metal (diameter: $1.9 \mathrm{~mm}$ ) was placed on the surface of the $\mathrm{H} 62$ brass substrates covered with FB102 (40 wt.\% of KF, $25 \mathrm{wt} . \% \mathrm{KBF}_{4}, 35 \mathrm{wt} . \%$ of $\mathrm{B}_{2} \mathrm{O}_{3}$ ), which was then heated at $750{ }^{\circ} \mathrm{C}$ for $1 \mathrm{~min}$ in an electrical resistance furnace. The spreading area was measured using the Image-Pro Plus software.

The phase and microstructure of the $\mathrm{Cu}-7 \mathrm{P}-1 \mathrm{Ag}-x \mathrm{Sn}$ filler metals were examined using an X-ray diffractometer (XRD, Bruker D8 Advance, Bruker, MA, USA, Range: $10^{\circ}-90^{\circ}$, Speed: $6^{\circ} / \mathrm{min}$, Voltage: $40 \mathrm{kV}$, Current: $150 \mathrm{~mA}$ ) and a scanning electron microscope (SEM, ZEISS $\Sigma$ IGMA 500, ZEISS, Oberkochen, Germany) equipped with an energy dispersive spectrometer (EDS, Bruker Nano XF Lash Detector 5010, Bruker, MA, USA). The flame brazing method was used in this study to braze the H62 brass, and the shear strength of joints with an overlap length of $2 \mathrm{~mm}$ and joint clearance of $0.07 \mathrm{~mm}$ was tested on an electronic universal testing machine, according to the China's National Standard GB/T 11363-2008 [16]. At least five specimens were tested for each experimental condition and the averages of the tested results were calculated. In addition, the fracture morphologies of H62 brass brazed joints were characterized using a scanning electron microscope (SEM). 


\section{Results}

\subsection{Thermal Properties and Spreading Performance of Cu-7P-1Ag-xSn Filler Metals}

Figure 1 shows the thermal properties of $\mathrm{Cu}-7 \mathrm{P}-1 \mathrm{Ag}-x \mathrm{Sn}$ filler metals. The results indicate that the solidus temperature $\left(\mathrm{T}_{\mathrm{S}}\right)$ and liquidus temperature $\left(\mathrm{T}_{1}\right)$ of the alloys decreased with increasing Sn content. Compared with $\mathrm{Cu}-7 \mathrm{P}-1 \mathrm{Ag}$, the $\mathrm{T}_{\mathrm{s}}$ and $\mathrm{T}_{1}$ of $\mathrm{Cu}-7 \mathrm{P}-$ $1 \mathrm{Ag}-1 \mathrm{Sn}$ filler metal were reduced to $560^{\circ} \mathrm{C}$ and $751^{\circ} \mathrm{C}$, respectively, representing decreases of $13.2 \%$ and $5.2 \%$, respectively. The decrease of both $\mathrm{T}_{\mathrm{s}}$ and $\mathrm{T}_{1}$ was likely due to the fact that the melting point of $\mathrm{Sn}$ is only $231.9^{\circ} \mathrm{C}$. Appropriate amounts of $\mathrm{Sn}$ could dissolve in copper to form copper-based solid solutions with lower melting temperature, which is beneficial for the brazing of the $\mathrm{H} 62$ brass substrate. The effect of alloying elements on the thermal properties of solder has been reported elsewhere [17-19], and its mechanism is similar to that described in this study. Notably, the $\mathrm{T}_{\mathrm{S}}$ of the brazing filler metal was $560{ }^{\circ} \mathrm{C}$ when the amount of Sn addition exceeded $0.5 \mathrm{wt} . \%$, indicating that the Cu-P-Ag-Sn quaternary eutectic structure of the novel low-silver filler metal had begun to emerge [20].
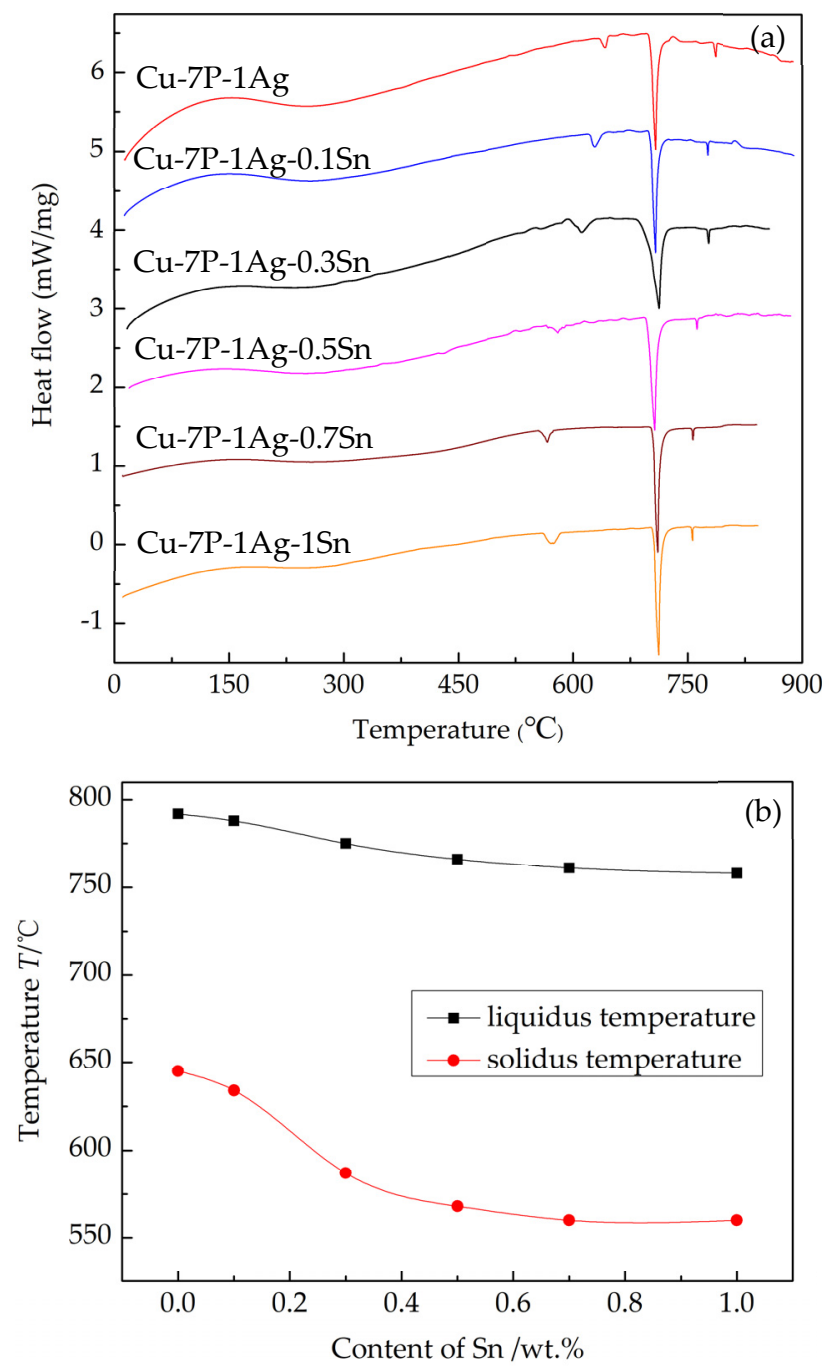

Figure 1. Melting behavior of Cu-7P-1Ag- $x$ Sn filler metals: (a) DSC melting curves of the filler metals, (b) The change trend of $T_{S}$ and $T_{1}$.

In general, the spreading area of liquid brazing filler metals on a substrate is usually used to evaluate the fluidity: the larger the spreading area, the better the fluidity [21]. Figure 2 presents the spreading test results of $\mathrm{Cu}-7 \mathrm{P}-1 \mathrm{Ag}-x \mathrm{Sn}$ filler metals on H62 brass substrates with the aid of FB102 flux at a temperature of $750{ }^{\circ} \mathrm{C}$. As shown in the figure, with an increase in Sn content from 0 to $1 \mathrm{wt}$ \%, the spreading area of the filler metals on 
H62 brass improved significantly, i.e., the spreading area of Cu-7P-1Ag-1Sn filler metal was about $13 \%$ larger than that of the Sn-free one. However, when the Sn content reached $0.5 \mathrm{wt} \%$, the growth rate of the spreading area began to slow down. Therefore, it can be inferred that the improvement in spreadability was due to the decrease of the melting temperature of the filler metals. Under the same brazing process parameters, the lower the melting point of the brazing filler metal, the greater the superheat and the lower the surface tension of the liquid alloy, which improves the spreadability of the filler metal on the substrate [22].

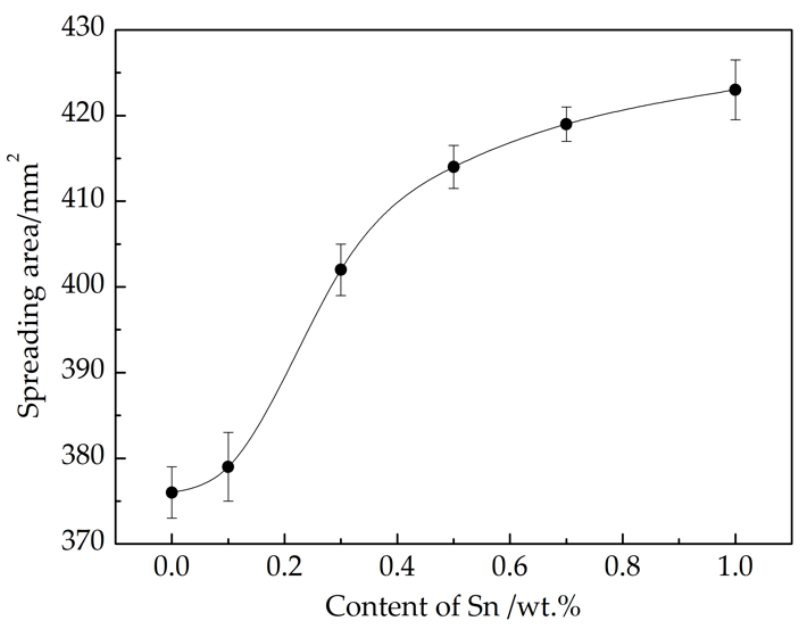

Figure 2. Spreading areas of $\mathrm{Cu}-7 \mathrm{P}-1 \mathrm{Ag}-x \mathrm{Sn}$ filler metals on $\mathrm{H} 62$ brass plates.

\subsection{Microstructure of $\mathrm{Cu}-7 \mathrm{P}-1 \mathrm{Ag}-x \mathrm{Sn}$ Filler Metals}

Figure 3 shows the $\mathrm{X}$-ray diffraction (XRD) patterns of $\mathrm{Cu}-7 \mathrm{P}-1 \mathrm{Ag}-x \mathrm{Sn}$ filler metals. As we can see from the picture, when the Sn content was less than $0.7 \mathrm{wt} . \%$, the novel filler metals consisted of three phases, i.e., the $\alpha$-Ag solid solution phase, $\alpha-\mathrm{Cu}$ solid solution phase and $\mathrm{Cu}_{3} \mathrm{P}$ compound phase, in which the brittle structure of $\mathrm{Cu}_{3} \mathrm{P}$ negatively influenced the mechanical properties of the alloy. Therefore, the $\mathrm{P}$ content in $\mathrm{Cu}-\mathrm{P}$ brazing filler metals should be closely monitored $[23,24]$. Notably, the solid solubility of $\mathrm{Sn}$ in $\mathrm{Cu}$ is limited at room temperature, and when the content of $\mathrm{Sn}$ reaches $1 \mathrm{wt} . \%$, the diffraction peak of the $\mathrm{Cu}_{20} \mathrm{Sn}_{6}$ intermetallic compound phase appears.

Figure 5 shows a high magnification SEM image of $\mathrm{Cu}-7 \mathrm{P}-1 \mathrm{Ag}-0.5 \mathrm{Sn}$ filler metal. According to the $\mathrm{Cu}-\mathrm{P}$ binary phase diagram, the maximum solid solubility of $\mathrm{P}$ in $\mathrm{Cu}$ is 3.5 at. \%, and the $\mathrm{P}$ content in $\mathrm{Cu}_{3} \mathrm{P}$ and eutectic phase $\left(\alpha-\mathrm{Cu}+\mathrm{Cu}_{3} \mathrm{P}\right)$ is 25 at.\% and 15.7 at.\%, respectively. Combining the results of the XRD patterns in Figure 3, it may be inferred that the dark region (named as $\mathrm{C}$ ) is a eutectic structure of $\mathrm{Cu}_{3} \mathrm{P}$ and $\alpha$-Cu solid solution, the grey region (named as $\mathrm{A}$ ) is a mixed phase of $\alpha-\mathrm{Cu}$ primary phase and eutectic phase $\left(\alpha-\mathrm{Cu}+\mathrm{Cu}_{3} \mathrm{P}\right)$, and the white region (named as B) is a mixed phase of $\alpha$-Ag solid solution, $\alpha-\mathrm{Cu}$ solid solution and $\mathrm{Cu}_{3} \mathrm{P}$. Notably, the $\mathrm{Sn}$ content in the B region was higher than in the $\mathrm{A}$ and $\mathrm{C}$ regions, which indicated that the $\mathrm{Ag}$ has a higher affinity for $\mathrm{Sn}$. The solidification process of the $\mathrm{Cu}-7 \mathrm{P}-1 \mathrm{Ag}-0.5 \mathrm{Sn}$ alloy occurred in three stages. First, the $\alpha-\mathrm{Cu}$ primary phase with a higher melting point formed. Second, as the temperature decreased, the eutectic phase increased with the precrystallized $\alpha-\mathrm{Cu}$ particles as the nucleation core. Finally, Ag-rich and Sn-rich phases with low melting points formed at the end.

Figure 4 shows SEM images of the studied $\mathrm{Cu}-7 \mathrm{P}-1 \mathrm{Ag}-x \mathrm{Sn}$ filler metals. As we can see from Figure $4 \mathrm{a}$, the microstructure of $\mathrm{Cu}-7 \mathrm{P}-1 \mathrm{Ag}$ filler metal showed thick dendrites intertwined with each other. As the Sn content in the brazing filler metal increased from 0 to $0.5 \mathrm{wt} . \%$, the microstructure of the filler metal gradually changed from thick dendrites into tiny worm-like structure. When the Sn content reached $1 \mathrm{wt} \%$, the microstructure of the filler metal transformed into a bulk, worm-like mixed structure. Similar results were reported by Huang et al. [14] in their study on the effect of trace amounts of Sn on the microstructure of $\mathrm{Cu}-6.5 \mathrm{P}$ filler metals. 


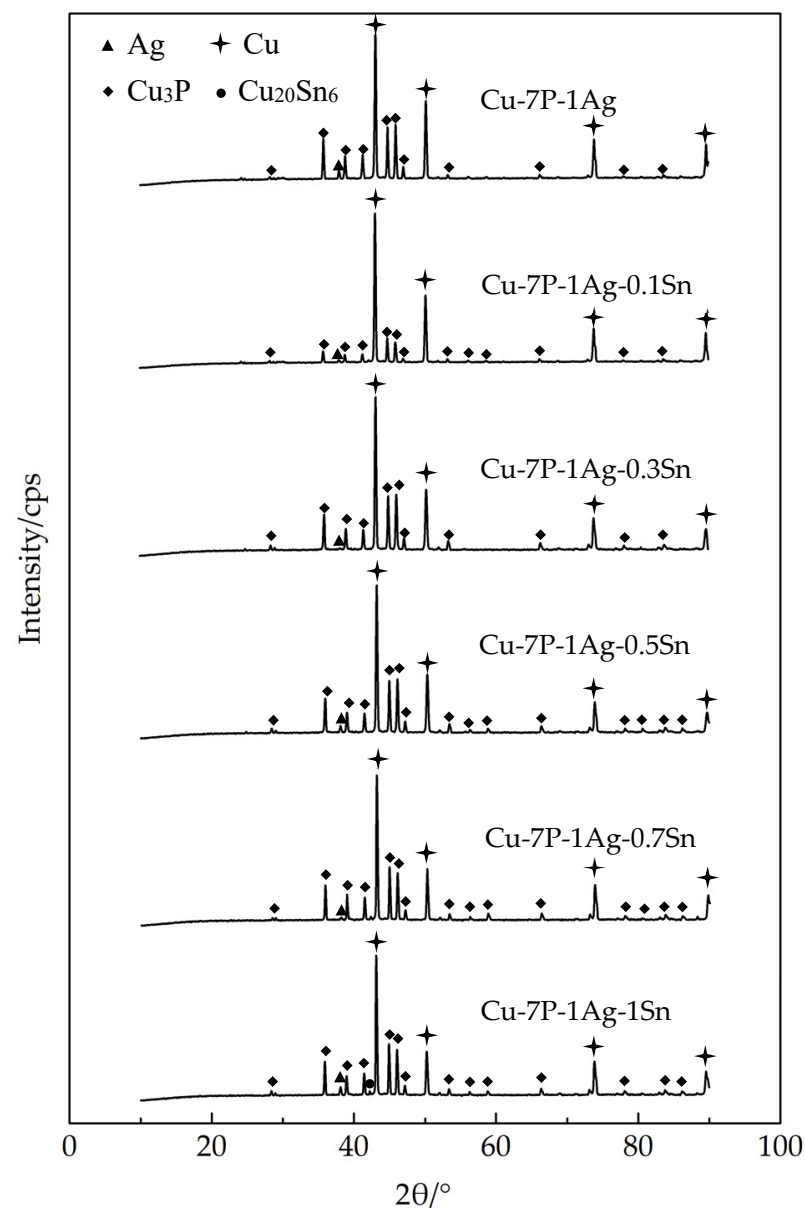

Figure 3. XRD patterns of Cu-7P-1Ag- $x$ Sn filler metals.

\subsection{Microstructure of the Brazed Joints}

The characteristics of the reaction layer formed at the interface between the filler metals and substrate can significantly affect the mechanical properties of brazed joints [25]. In order to investigate the effect of $\mathrm{Sn}$ content in low-silver $\mathrm{Cu}-\mathrm{P}$ filler metal on the performance of brazed joints, Cu-7P-1Ag filler metals with different Sn content were applied. Figure 6 shows the interfacial structures of the brass brazed joints using $\mathrm{Cu}-7 \mathrm{P}-1 \mathrm{Ag}-x \mathrm{Sn}$ filler metals. It can be seen in Figure 6a that the brazing seam of $\mathrm{Cu}-7 \mathrm{P}-1 \mathrm{Ag}$ filler metal was mainly composed of the white, grey bulk and dark phases, and that the white phase was distributed around the grey bulk phase. When the content of $S n$ in the filler metal increased from 0 to $0.7 \mathrm{wt} . \%$, the grey phase of the brazed joints gradually changed from a bulk to a lamellar structure. In contrast, as shown in Figure $6 \mathrm{f}$, when the Sn content increased to $1 \mathrm{wt}$. \%, some large grey phases were formed in the brazing seam, which may have negatively affected the mechanical properties of the brazed joints.

A high magnification SEM image of a Cu-7P-1Ag-1Sn brazing seam, the element mappings and an EDS analysis of point in (a) are shown in Figure 7. These data indicate that the element mappings of $\mathrm{P}$ and Ag overlapped with the dark and white phases, respectively, and that the Sn-rich phase surrounded the grey phase. Combined with the results of EDS, it can be inferred that the white phase (named as A) was a mixed phase of $\alpha-\mathrm{Ag}, \alpha-\mathrm{Cu}$ and $\mathrm{Cu}_{3} \mathrm{P}$, the dark phase (named as $\mathrm{B}$ ) was a eutectic phase of $\alpha-\mathrm{Cu}$ and $\mathrm{Cu}_{3} \mathrm{P}$, and the grey phase (named as $\mathrm{C}$ ) was a mixed phase of the $\alpha$-Cu primary and eutectic phases $\left(\alpha-\mathrm{Cu}+\mathrm{Cu}_{3} \mathrm{P}\right)$, which is similar to the phase characteristics of brazing filler metals. Notably, compared with the $B$ and $C$ regions in the brazing seam matrix, the $P$ content of the reaction layer (named as D) which formed at the interface between the filler metals and 
the H62 brass substrate was significantly reduced, and the content of Ag and Sn was higher, indicating that $\mathrm{Ag}$ and $\mathrm{Sn}$ had a higher diffusion coefficient in the H62 brass than P.
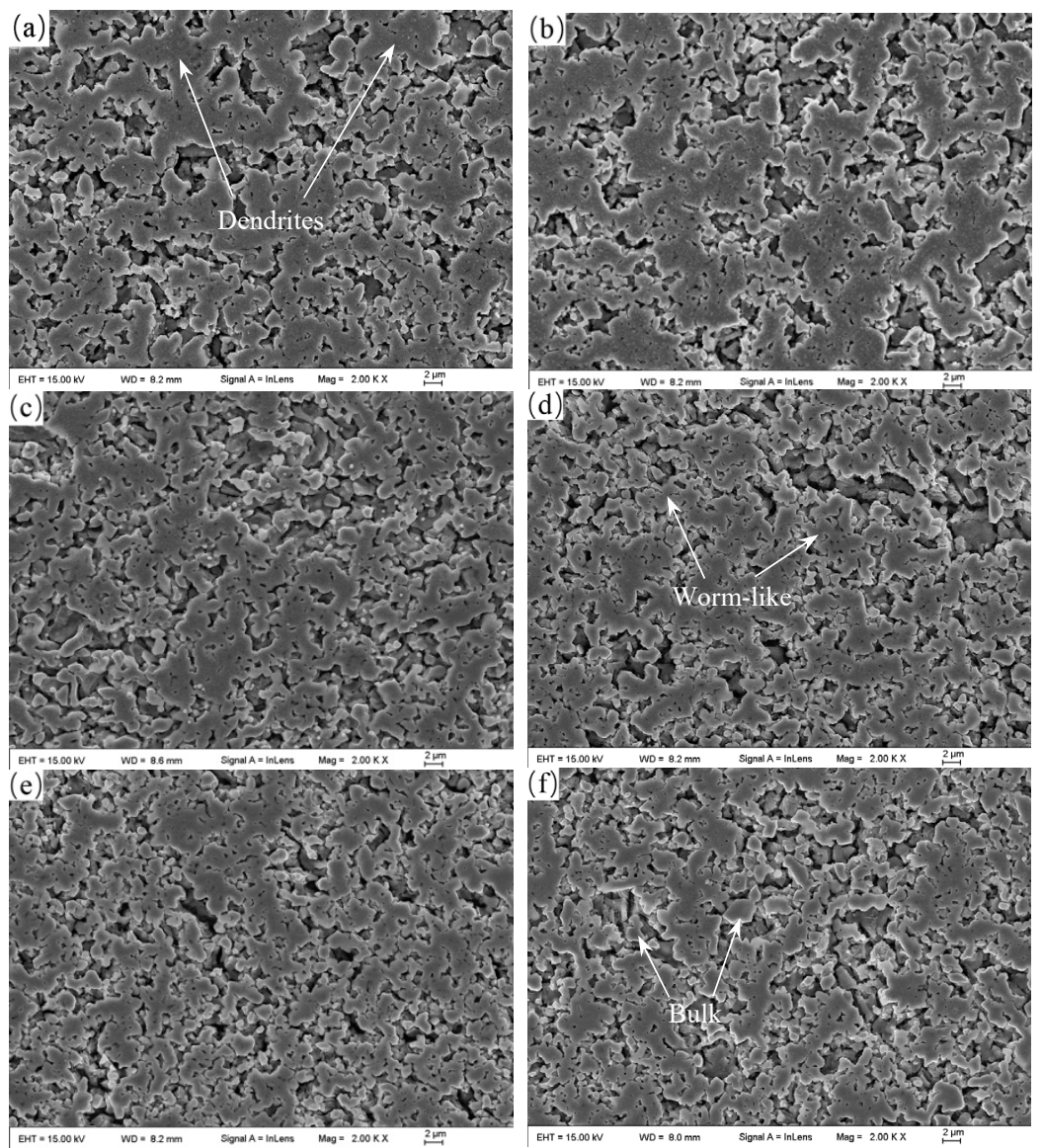

Figure 4. SEM images of Cu-7P-1Ag- $x \mathrm{Sn}$ filler metals: (a) Cu-7P-1Ag, (b) Cu-7P-1Ag-0.1Sn, (c) Cu7P-1Ag-0.3Sn, (d) Cu-7P-1Ag-0.5Sn, (e) Cu-7P-1Ag-0.7Sn, (f) Cu-7P-1Ag-1Sn.

\subsection{Mechanical Property of the Brazed Joints}

The shear strength of the H62 brass lap joint was gradually enhanced when the content of Sn increased from 0 to $0.5 \mathrm{wt} . \%$, as shown in Figure 8. Fractures occurred in the brazed joints of the $\mathrm{H} 62$ brass brazed specimens in all cases during shear tests. The results show that the peak shear strength of the joints reached a maximum of $348 \mathrm{MPa}$ when the Sn content was $0.5 \mathrm{wt} . \%$, which increased by $21.6 \%$ compared to the Sn-free one. The improvement of the shear strength of brazed joints with a trace amount of Sn may be explained by the microstructure of the brazing seam, as shown in Figure 7, where Sn had a higher diffusion coefficient in $\mathrm{H} 62$ brass than $\mathrm{P}$, while $\mathrm{Sn}$ could be dissolved in $\mathrm{Cu}$ to form a Cu-based solid solution, the strengthening effect of which may have improved the shear strength of brazed joints.

However, the mechanical properties of the joints degenerated with further increases of Sn content. When the Sn content reached 1 wt.\%, the shear strength of the H62 brass joint brazed with Cu-7P-1Ag-1Sn filler metal was reduced to $311 \mathrm{MPa}$. The decrease in shear strength may have been due to the form of $\mathrm{Cu}_{20} \mathrm{Sn}_{6}$ intermetallic compound. Zhao [26] reported that the hardness of $\mathrm{Cu}_{20} \mathrm{Sn}_{6}$ is extremely high, which easily become the stress concentration areas and deteriorate the mechanical property of the alloy. 

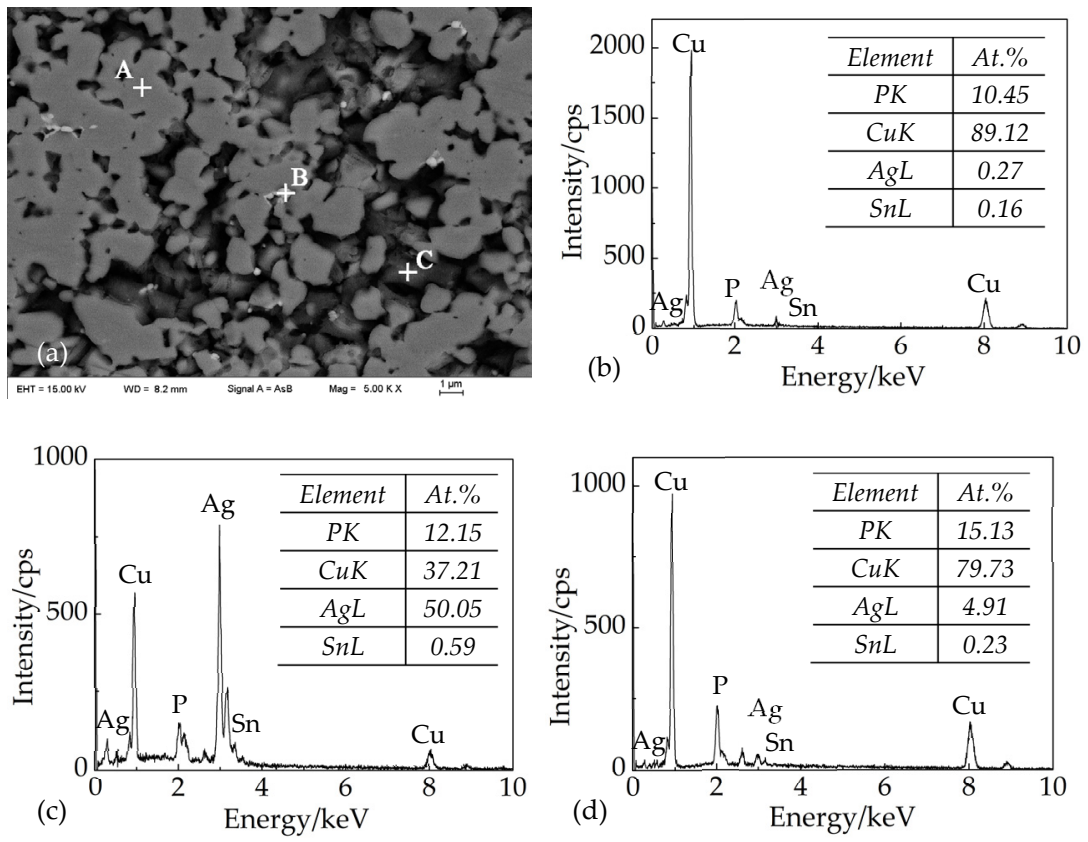

Figure 5. (a) High magnification SEM images of Cu-7P-1Ag-0.5Sn filler metals, (b) EDS analysis of point A in (a), (c) EDS analysis of point B in (a), (d) EDS analysis of point C in (a).
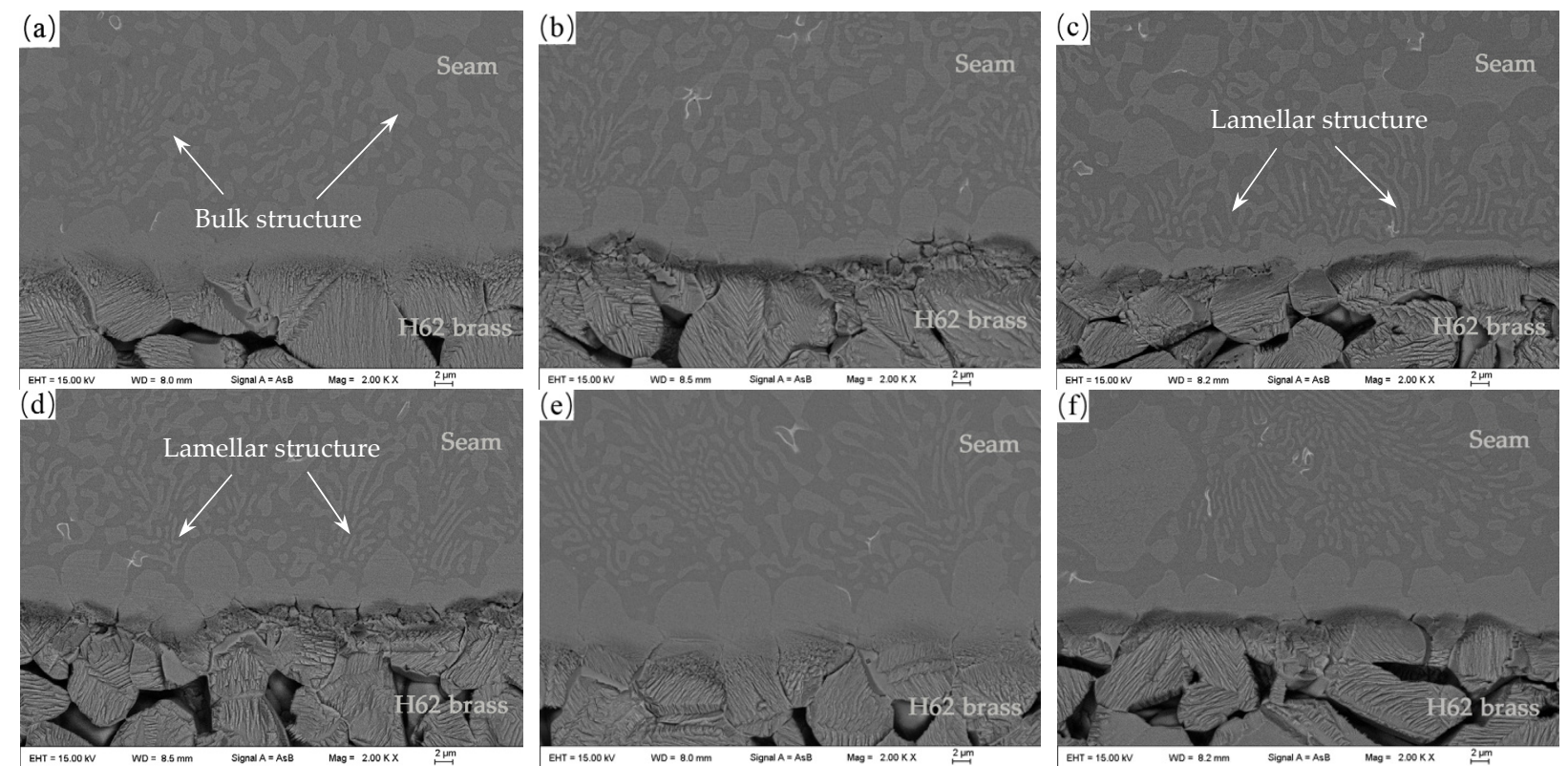

Figure 6. Interface microstructures of the brass brazed joints using different low-silver filler metals: (a) Cu-7P-1Ag, (b) Cu-7P-1Ag-0.1Sn, (c) Cu-7P-1Ag-0.3Sn, (d) Cu-7P-1Ag-0.5Sn, (e) Cu-7P-1Ag-0.7Sn, (f) Cu-7P-1Ag-1Sn. 

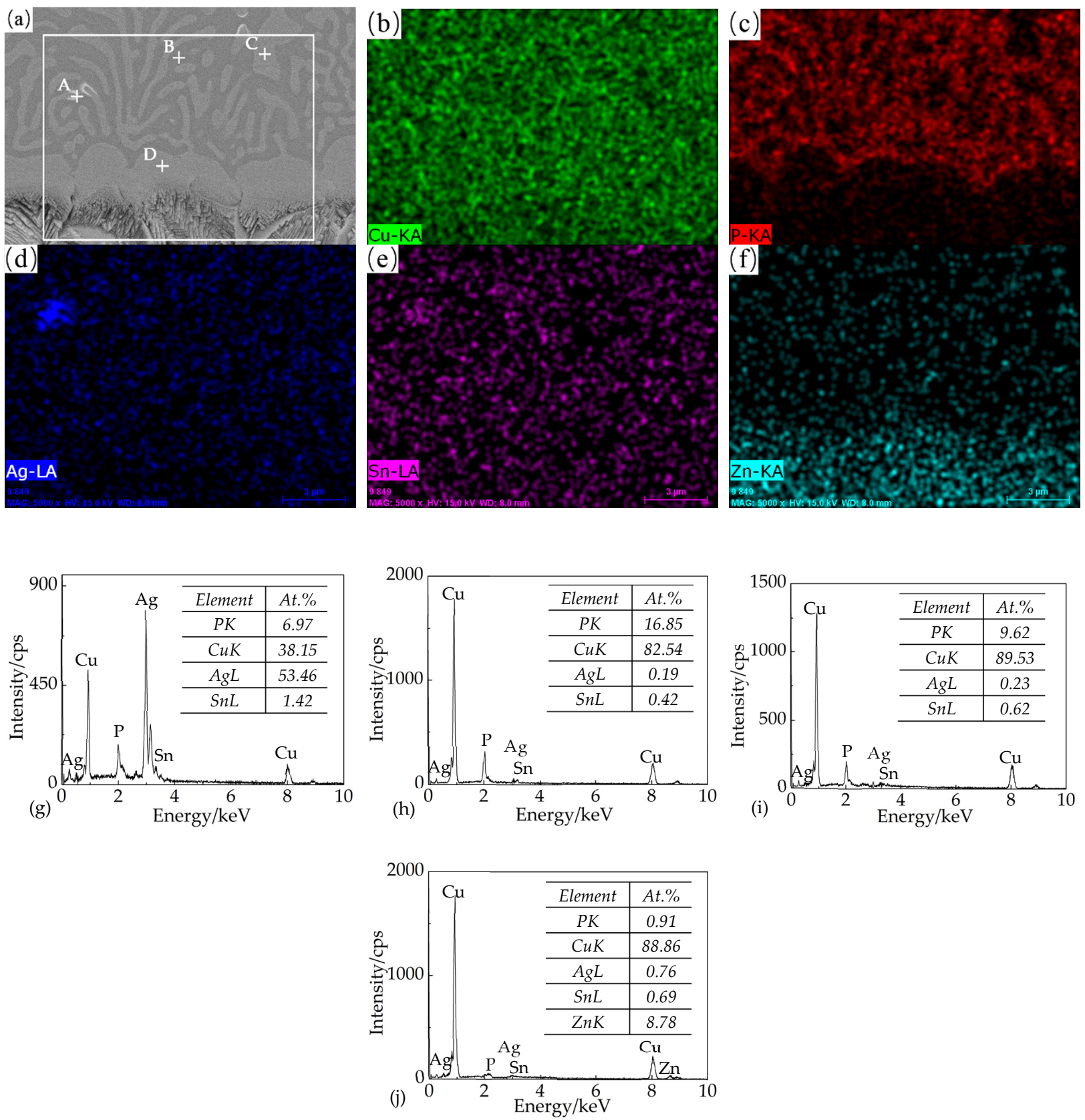

Figure 7. SEM images of interfacial microstructure of $\mathrm{Cu}-7 \mathrm{P}-1 \mathrm{Ag}-1 \mathrm{Sn}$ brazing seam and corresponding the element mapping of the area marked with white square in (a): (b) Cu, (c) P, (d) Ag, (e) Sn, (f) Zn, (g) EDS analysis of point A in (a), (h) EDS analysis of point B in (a), (i) EDS analysis of point C in (a), (j) EDS analysis of point D in (a).

The fracture morphologies of $\mathrm{H} 62$ brass joints brazed with Cu-7P-1Ag- $x \mathrm{Sn}$ filler metals are shown in Figure 9. The results show that the fracture morphology of the joint brazed with $\mathrm{Cu}-7 \mathrm{P}-1 \mathrm{Ag}$ filler metal presented the brittle characteristics of a river-like pattern, which indicated that a cleavage fracture had occurred. With the addition of Sn, secondary cracks and tearing edges began to appear in the fracture morphologies, which indicated that the fracture type had changed from cleavage into quasi-cleavage fractures, and thus, that the mechanical properties of brazed joints had improved. However, when the content of Sn reached $1 \mathrm{wt} . \%$, the secondary cracks in the fracture morphology disappeared. The fracture morphology in Figure $9 \mathrm{f}$ shows a typical brittle fracture. All of the above analyses indicate that the content of $\mathrm{Sn}$ in $\mathrm{Cu}-7 \mathrm{P}-1 \mathrm{Ag}$ filler metal should be kept below $0.7 \mathrm{wt} . \%$. 


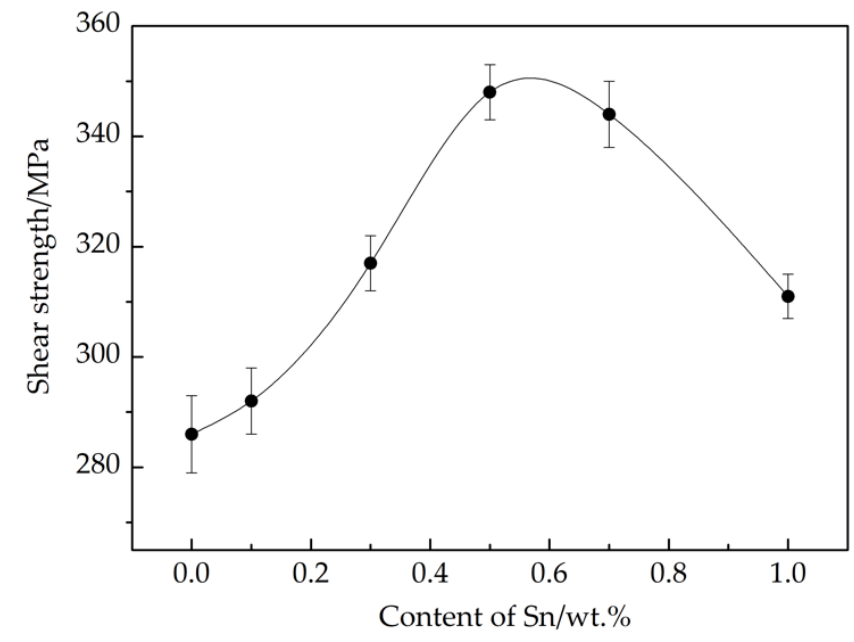

Figure 8. Shear strengths of the H62 brass lap joints using Cu-7P-1Ag- $x$ Sn.
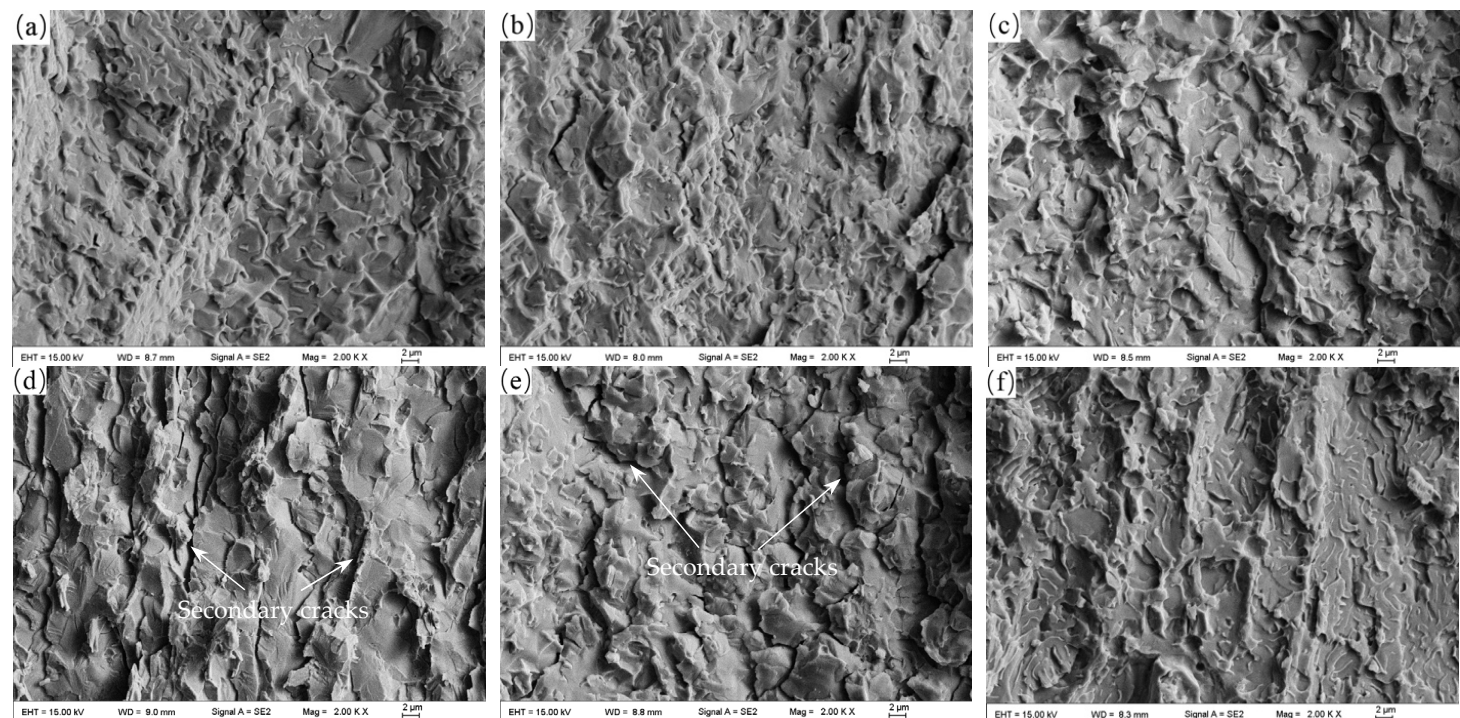

Figure 9. Fracture morphologies of the brazed joints using $\mathrm{Cu}-7 \mathrm{P}-1 \mathrm{Ag}-x \mathrm{Sn}$ filler metals: (a) Cu-7P1Ag, (b) Cu-7P-1Ag-0.1Sn, (c) Cu-7P-1Ag-0.3Sn, (d) Cu-7P-1Ag-0.5Sn, (e) Cu-7P-1Ag-0.7Sn, (f) Cu7P-1Ag-1Sn.

\section{Conclusions}

The effect of Sn on the melting characteristics, spreadability, and microstructures of $\mathrm{Cu}-7 \mathrm{P}-1 \mathrm{Ag}$ brazing filler metals was studied. Additionally, the mechanical properties of $\mathrm{H} 62$ brass joints brazed with different low-silver $\mathrm{Cu}-\mathrm{P}$ filler metals were investigated. The following conclusions can be drawn from this study:

(1) The solidus and liquidus temperatures of $\mathrm{Cu}-7 \mathrm{P}-1 \mathrm{Ag}-x \mathrm{Sn}$ filler metals decrease with the addition of Sn. Meanwhile, the spreadability of the filler metals on H62 brass substrates is significantly improved.

(2) $\mathrm{Cu}-7 \mathrm{P}-1 \mathrm{Ag}-x \mathrm{Sn}$ filler metals are mainly comprised of $\alpha$-Ag solid solution, $\alpha$-Cu solid solution and $\mathrm{Cu}_{3} \mathrm{P}$. $\mathrm{Cu}_{20} \mathrm{Sn}_{6}$ compound is formed in the matrix of $\mathrm{Cu}-7 \mathrm{P}-1 \mathrm{Ag}-1 \mathrm{Sn}$ filler metal. With the addition of $\mathrm{Sn}$, the microstructure of the filler metal gradually changes from thick dendrites into tiny worm-like structures.

(3) With increasing Sn content, the microstructure of the brazed joints gradually changes from a bulk to a lamellar structure. Ag and Sn have higher diffusion coefficients into H62 brass substrate than P. 
(4) The strength of H62 brass brazed joints presents a parabolic trend according to Sn content. A peak value of $348 \mathrm{MPa}$ was achieved using Cu-7P-1Ag-0.5Sn filler metal. The fracture morphology of the joint brazed with $\mathrm{Cu}-7 \mathrm{P}-1 \mathrm{Ag}-0.5 \mathrm{Sn}$ showed quasicleavage fractures with secondary cracks and tearing edges, whereas when $\mathrm{Cu}-7 \mathrm{P}-1 \mathrm{Ag}$ 1Sn was studied, the fracture surface showed typical brittle fracture characteristics.

Author Contributions: Conceptualization, S.X.; methodology, Q.L.; software, J.W.; validation, J.W.; formal analysis, J.W.; investigation, J.W.; resources, J.W.; data curation, J.W.; writing-original draft preparation, J.W.; writing-review and editing, J.W.; visualization, J.W.; supervision, S.X.; project administration, S.X.; funding acquisition, S.X. All authors have read and agreed to the published version of the manuscript.

Funding: This work was funded by the National Natural Science Foundation of China, Grant No. 51975284, and the Priority Academic Program Development of Jiangsu Higher Education Institutions (PAPD).

Acknowledgments: The authors sincerely acknowledge the financial supports by the National Natural Science Foundation of China, Grant No. 51975284, as well as the Priority Academic Program Development of Jiangsu Higher Education Institutions (PAPD).

Conflicts of Interest: The authors declare no conflict of interest.

\section{References}

1. Xue, S.B.; Wang, B.; Zhang, L.; Long, W.M. Development of green welding technology in China during the past decade. Mater. Rep. 2019, 33, 2813-2830.

2. Xu, X.P.; Ma, Q.J.; Xia, C.Z. Micromorphology change and microstructure of $\mathrm{Cu}-\mathrm{P}$ based amorphous filler during heating process. High Temp. Mater. Process. 2019, 38, 651-661. [CrossRef]

3. Luo, Q.C.; Xue, S.B.; Wu, J. Influences of Sn on properties of Ag-based and Cu-based brazing filler metals. Crystals 2021, 11, 1403. [CrossRef]

4. $\quad$ Li, Y.N.; Wang, C.W.; Peng, Z.L.; Yan, J.C.; Liu, X.S. Dissolution behavior of Cu in Cu-Ag and Cu-P brazing alloys using weld brazing. Trans. Nonferrous Met. Soc. China 2011, 21, 394-399. [CrossRef]

5. Xie, W.H.; Yang, Y.Z.; Chen, W.L.; Liu, M. Effects of Ni element on properties of Cu-P amorphous filler metal. Hot Work. Technol. 2015, 44, 23-25.

6. Terasaki, T.; Kon, N.; Chiba, H.; Ohashi, T.; Nagatomo, Y.; Kuromitsu, Y.; Knowles, K.M. Interfacial structure between aluminum nitride and Cu-P-Sn-Ni brazing alloy with Ti film. J. Mater. Sci. 2021, 56, 8778-8788. [CrossRef]

7. Jattakul, P.; Kanlayasiri, K. Influences of solid-state brazing conditions on microstructure and tensile shear force of Ag-Cu-P brazed copper sheets. IOP Conf. Ser. Mater. Sci. Eng. 2018, 361, 012001. [CrossRef]

8. Sami, M.M.; Zaharinie, T.; Yusof, F.; Ariga, T. Investigation on strength and microstructural evolution of porous $\mathrm{Cu} / \mathrm{Cu}$ brazed joints using Cu-Ni-Sn-P filler. Metals 2020, 10, 416. [CrossRef]

9. Yang, K.Z.; Liu, Z.L.; Liu, F.M.; Liu, S.T. Effects of Sn on properties of Cu-P filler metals. Hot Work. Technol. 2011, 40, 41-43.

10. Gao, F.; Xu, W.L.; Wang, C.; Zou, J.S. Strength and microstructure of $\mathrm{Cu}$ joints brazed with Cu-P brazed amorphous filler metal contained Zr. Trans. China Weld. Inst. 2011, 32, 53-56.

11. Jiang, F.; Liu, H.; Wen, K.; Xu, H.H. Effects of La, Ce and Si co-addition on wettability of copper phosphorus brazing filler metal and microstructure of brazing seam. Hot Work. Technol. 2013, 42, 202-205.

12. Zhai, Z.M. The Effect of Alloy Element and Brazing Process on Cu-P-Ag Brazing Performance. Master's Thesis, Central South University, Changsha, China, 2014.

13. Li, Y.; Lu, J.B.; Mu, Y.C.; Xu, S.; Qiu, X.K. Effect of Cu-P-Sn on vacuum brazing of diamond by Ni based filler metal. Hot Work. Technol. 2018, 47, 58-61.

14. Huang, J.L.; Long, W.M.; Zhang, G.X. Effects of Sn on properties and microstructures of Cu-P filler metal. JWJ 2012, 3, 57-60.

15. GB/T 11364-2008. Test Method of Wettability for Brazing Filler Metals; Standardization Administration: Beijing, China, 2008.

16. GB/T 11363-2008. Test Method of the Strength for Brazed and Soldered Joint; Standardization Administration: Beijing, China, 2008.

17. Shalaby, R.M.; Kamal, M.; Ali, E.A.M.; Gumaan, M.S. Microstructure and mechanical characterization of melt spun process Sn-3.5Ag and Sn-3.5Ag-xCu lead-free solder for low cost electronic assembly. Mater. Sci. Eng. A 2017, 690, 446-452. [CrossRef]

18. Jubair, M.M.; Gumaan, M.S.; Shalaby, R.M. Reliable Sn-Ag-Cu lead-free melt-spun material required for high-performance applications. Z. Kristallogr. Cryst. Mater. 2019, 234, 757-767. [CrossRef]

19. Abbas, S.R.; Gumaan, M.S.; Shalaby, R.M. Chromium effects on the microstructure, mechanical and thermal properties of a rapidly solidified eutectic Sn-Ag alloy. Solder. Surf. Mt. Technol. 2020, 32, 137-146. [CrossRef]

20. Zhang, Q.Y.; Zhuang, H.S. Handbook of Brazing and Soldering, 3rd ed.; China Machine Press: Beijing, China, 2018; pp. 109-134.

21. Zhao, Z.Y.; Li, T.; Duan, Y.R.; Wang, Z.C.; Li, H. Wetting and coalescence of the liquid metal on the metal substrate. Chin. Phys. B 2017, 26, 140-146. [CrossRef] 
22. Lai, Z.M.; Xue, S.B.; Han, X.P.; Gu, L.Y.; Gu, W.H. Study on microstructure and property of brazed joint of AgCuZn-X (Ga, Sn, In, Ni) brazing alloy. Rare Met. Mater. Eng. 2010, 39, 397-400.

23. Hissyam, W.N.W.M.N.; Halil, A.M.; Kurniawan, T.; Ishak, M.; Ariga, T. Effect of copper-based fillers composition on spreading and wetting behaviour. IOP Conf. Ser. Mater. Sci. Eng. 2017, 238, 012020. [CrossRef]

24. Wang, L. Study on Properties and Brazing Mechanism of Cu-P Based Amorphous Filler Metal. Master's Thesis, Jiangsu University of Science and Technology, Zhenjiang, China, 2010.

25. Ji, F.; Xue, S.B.; Dai, W. Effects of Ti on the brazability of Zn-22Al-xTi filler metals as well as properties of Cu/Al brazing joints. Rare Met. Mater. Eng. 2013, 42, 2453-2457.

26. Zhao, Z.X.; Zeng, P.; Xie, G.R.; Zhong, G.M.; Chen, D.C.; Xu, X.D. Study on composition control and performance of brush plated copper-tin alloy deposits. Electroplat. Met. Finish. 2015, 34, 595-601. 